\title{
Vietnam Television giới thiệu sách Kinh tế Việt Nam: Thăng trầm và đột phá
}

\author{
Ngọc Hà \\ Vietnam Television \\ June 17, 2009 \\ URL: https://vtv.vn/trong-nuoc/kinh-te-viet-nam-thang-tram-va-dot- \\ pha--33364.htm
}


CHÍNH TR! XÃ HỌI PHÁP LUẬt THÉ GIỚl KINH TÉ THẺ THAO TRUYÈn HİNH GIẢl TRÍ S

\section{TRONG NƯỚC}

\section{"Kinh tế Việt Nam - Thăng trầm và đột phá"}

Ngọc Hà - Thứ tư, ngày 17/06/2009 09:13 GMT+7

\section{It Thích Chia sẻ}

Không thể không tự hỏi, sự phát triển trong hơn 20 năm Đổi Mới của Việt Nam nằm ở đâu trong lịch sử của dân tộc, của nền kinh tế toàn cầu đương đại và của số phận nhân loại? Có lẽ, không một ai, với sự tâm huyết dành cho dân tộc Việt Nam, sự trăn trở và những nỗ lực của người Việt Nam, lại không thấy được nỗi truân chuyên của một hành trình đầy thăng trầm, những bước đột phá và cả những bài học sâu sắc, không chỉ dành cho nhận thức lịch sử, mà còn có cả ý nghĩa hướng tới giải pháp tương lai.

"Kinh tế Việt Nam - Thăng trầm và đột phá” là tác phẩm của 2 tác giả Phạm Minh Chính và Vương Quân Hoàng, là công trình nghiên cứu một giai đoạn phát triển sôi động bậc nhất của nền kinh tế Việt Nam thời kỳ đổi mới. Cuốn sách sẽ giúp bạn đọc có thêm tài liệu nghiên cứu, tham khảo về lịch sử phát triển Việt Nam, đánh giá được các yếu tố bên ngoài mà nền kinh tế nước ta phải đương đầu trong năm 2009 và những năm tiếp theo.

Đặt trọng tâm nghiên cứu là hệ thống thị trường và phương tiện kiểm soát tài chính tiền tệ, cuốn sách tập trung nghiên cứu sâu về các thị trường bất động sản, thị trường vàng và đôla $\mathrm{Mỹ}$, thị trường chứng khoán Việt Nam. Có thể nói "Kinh tế Việt Nam - Thăng trầm và đột phá" là một trong rất ít sách viết về các thị trường này với nhiều thông tin và nhận định sắc sảo, có giá trị gợi mở suy nghĩ.

Các tác giả cũng đã phân tích về các vấn đề và hiện tượng đặc trưng có tính phổ quát trong nền kinh tế: Bong bóng tài sản tồn tại cả với thị trường bất động sản và thị trường chứng khoán.

Hiện tượng "bầy đàn" thể hiện rất rõ ràng qua hình ảnh chen nhau mua vàng vào lúc giá lên, vay mượn mua chứng khoán lúc VN-Index ở đỉnh, thế rồi, lại đổ xô đi 
đặt lệnh bán khi chỉ số giá sụt giảm.

Dày hơn 500 trang, cuốn sách này phác hoạ bức tranh toàn cảnh nền kinh tế Việt Nam từ khi giành được độc lập đến nay với mong muốn để lại trong độc giả những suy nghĩ về hành trình tiếp tục chinh phục nền kinh tế toàn cầu cùng giấc mơ nước Việt Nam thịnh vượng.

PGS.TS Trần Đình Thiên, Quyền Viện trưởng Viện kinh tế Việt Nam nhận xét: "Kinh tế Việt Nam - thăng trầm và đột phá" là sự kết nối lịch sử với hiện tại. Đề cập một cách tự nhiên các vấn đề thời sự nóng bỏng của nền kinh tế trong 2 năm gia nhập Tổ chức thương mại thế giới (WTO) và chịu tác động mạnh mẽ của cuộc khủng hoảng kinh tế - tài chính toàn cầu. "Kinh tế Việt Nam - thăng trầm và đột phá” không còn là một cuốn sách sử, mà là công trình nghiên cứu các vấn đề đương đại. Các nhận định, bình luận của cuốn sách mang tính phản biện cao, với một thái độ, trách nhiệm đầy đủ.

"Nhìn giai đoạn lịch sử được đánh giá chung là "thành công ngoạn mục" không chỉ qua các sự kiện "đột phá" oai hùng, mà quan trọng hơn, qua diễn biến "thăng trầm" gắn với những khó khăn, yếu kém và sai sót trong việc lựa chọn và thực thi một phương pháp cách phát triển "chưa có tiền lệ lịch sử” bằng con mắt phê phán khoa học, có thể coi là nét đặc sắc nổi bật nhất của cuốn sách này”.

Mổ xẻ nền kinh tế Việt Nam bằng những công cụ phân tích tài chính, cuốn sách của Phạm Minh Chính và Vương Quân Hoàng lôi cuốn người đọc với nhiều gợi mở thảo luận, tư liệu và sự kiện đậm đặc tính thời sự. Sách do Nhà xuất bản Chính trị Quốc gia ấn hành.

Bấm like dể theo dố thông tin chính thống, tin cậy tù Báo diện tử VTV

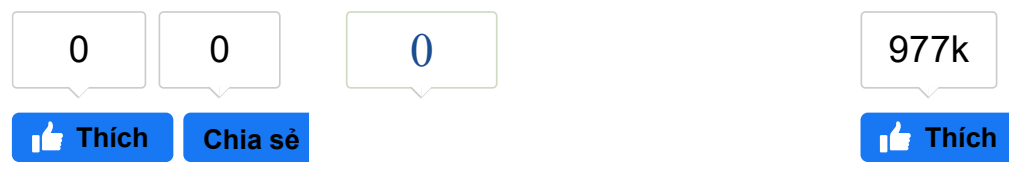




\section{Tài liệu tham khảo:}

[1] Phạm Minh Chính, Vương Quân Hoàng. (2009). Kinh tế Việt Nam: Thăng trầm và đột phá. Nxb Chính trị quốc gia, Hà Nội.

[2] Phạm Minh Chính, Vương Quân Hoàng. (2008). Bối cảnh tài chính Việt Nam 1997-1998 và 2007-2008: Khoảng cách và biến đối. Nghiên cứu Kinh tế, 48(7), 3-24. 